\title{
STUDIES ON THE BITING-LICE (MALLOPHAGA) OF JAPAN AND ADJACENT TERRITORIES (SUBORDER ISCHNOCERA Pt. II)
}

\author{
By SeINosuke UCHIDA \\ Institute for Ornitholosy and Mammalogy, Department of Forestry, \\ Ministry of Agriculture and Forestry, Tokyo
}

\section{Genus PHILOPTERUS Nitzsch.}

Nitzsch, 1818, p. 288.

Phylopterus $\boldsymbol{r}$ :lly (Denny).

Docophorus ralli Denny, 1842, p. 75, pl. V, fig. 6; Piaget, 1880, p. 79.

1 f from an Eastern water-rail, Rallus quaticus indicus Blyth, taken in Pref. Nagano.

Philopterus integer (Nitzsch).

Docophorus integer Nitzsch, in Giebel, 1874, p. 95; Piaget, 1880, p. 99.

$4 \hat{\delta}, 2 \odot, 10^{\ominus}$ were taken on a hooded crane, Grus monacha Temminck shot in Corea, Feb. 18, 1914.

\section{Philopterus wumisuzume* n. sp. (Fig. 9).}

1 \% was obtained from a crested auk, Aethia cristatella (Pallas), shot in the Id. Ushishiru, of the Kurile Ids.

This new species belongs to Piaget's group trianguliferi infesting the water birds and characterized by the large, semi-circular clypeus with triangular blotches on each side. The new species somewhat resembles Docophorus procax Kellogg** and also D. alaskensis Kellogg and Kuwana*** in the shape of the forehead and long, narrow clypeus; but it differs from the former in having very distinct, characteristic occipital band and from the latter in having larger and more expanded, uncoloured portion of clypeus.

Description of the female:-Body, length $1.63 \mathrm{~mm}$, width $0.70 \mathrm{~mm}$; with remarkably long head; ground colour of body pale yellowish brown with distinct dark brown márkings on head, thorax and abdomen; occipital band and transverse blotches of abdomen yellowish brown.

Head oblong, conical; length $0.57 \mathrm{~mm}$, width $0.48 \mathrm{~mm}$; temples short, somewhat expanded lateraly; uncoloured front of clypeus expanded anterolaterally, flatly rounded, front slightly convex; no hairs on the rouning, uncoloured clypeal region, but two short hairs at the point where the clypeus begins to swell beyond the sides of the head; a short prickle at the suture and also a short prickle just in front of the trabeculae; trabeculae large, blunt, reaching to the end of the second segment of the antennae;

* "Wumisuzume" in Japanese means Auks.

** Kellogg, New Mallophaga III, 1899, p. 54, pl. V, fig. 1.

*** Kellogg and Kuwana, Proc. Ac. Nal. Sci. Phil., 1900, p. 151, pl. VII. fig. 1. 
antennae short, with the second segment longest, segment third and fourth shortest and equal, segment fifth a little longer than the third, the basal segment thickend; eyes fiat, with a short hair and a prickle; temples short, rounded, with two hairs and a prickle; signature long, shield-shaped with truncate anterior margin, posterior acuminate point darker coloured; antennal bands distinct blackish brown, interrupted by the suture and turning in at the suture, become pale and narrower and nearly meeting on the median line, the posterior ends of the antennal bands bend acutely inward at the base of the trabeculae; occipital bands distinct, yellowish brown, strongly diverging anteriorly and bend outward to the ocular fleck and plainly separated from antennal bands by a broad uncoloured space, this region of occipital band is narrow and sinuous; occipital margin nearly straight but slightly convex in middle.

Prothorax, length $0.16 \mathrm{~mm}$, width $0.28 \mathrm{~mm}$; with sides diverging; posterior angle rounding, with a hair; lateral bands distinct, dark brown, extending in along the posterior margin. Metathorax, length $0.22 \mathrm{~mm}$, width $0.37 \mathrm{~mm}$; pentagonal, sides strongly diverging, posterior margin angular with slightly rounding tip on the abdomen, bearing seven pustulated hairs on each posterior margin beginning at lateral angles; lateral bands distinct dark brown; segment pale in the middle, growing darker laterally. Legs short, paler than body with brown marginal markings.

Abdomen elongate, ovate; length $0.82 \mathrm{~mm}$, width $0.70 \mathrm{~mm}$; widest at the fifth segment, posterior angles V-VII with two hairs, segment VIII large, rounded margin, with several hairs, the last segment small, uncoloured with emarginations; lateral bands distinct, dark brown, which become indistinct on posterior segment and end at sixth segment, transverse blotches yellowish brown, narrower inward, and leaving a broad whitish median space, widest at segments V, VI and narrowing on each successive segment; transverse blotch on segment VIII forms one continuous blotch, along the posterior margins of transverse blotch are partially uncoloured spot bearing long hairs on segment I one, segment II two, segment III three, segment IV four; segment V five, segment VI four, segment VII two;

\section{Philopterus montereyi (Kellogg).}

Docophorus montereyi Kellogg, 1896 a, p. 87, pl. III, fig. 6.

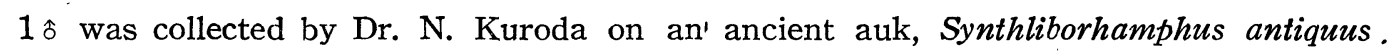
(Gmelin) shot in Pref. Shizuoka.

\section{Philopterus megacephalus (Denny).}

Docophorus megacephalus Denny, 1842, p. 86, pl. V, fig. 5; Waterston, 1914 b, p. 154; 1915, p. 175; Docophorus procax Kellogg. 1899, p. 54. pl. V, fig. 1.

Numerous specimens of both sexes were obtained on a sooty guillemot, Uria carbo (Pallas), in Pref. Chiba, Jan. 1925.

\section{Philopterus gonothorax (Giebel).}

Docophorus gonothorax Giebel, 1874, p. 111; Piaget, 1880, p. 111, pl. IX, flg. 7.

$3 \hat{\delta}, 4 \circ$ were collected from a black-tailed gull, Larus crassirostris Vieillot, killed in Pref. Aomori, Aug. 21, 1921 and 1 o, 2 f from a Pacific kittiwake, Rissa tridactyla pollicalis 
Ridgway shot in the Id. Enoshima, Pref. Kanagawa, March 17, 1918.

Philopterus albemarlensis (Kellogg and Kuwana).

Docophorus albemarlensis Kellogg and Kuwana, 1902, p. 465, pl. XXVIII, fig. 5; Uchida, 1918 , p. $483 ; 1920$, p. 636 .

The following specimens were collected from three species of terns.

3 \% Sterna sumatrana smatrana Raffles.

Ponape Id. IV, 29, 1914.

$2 \hat{\circ}, 3 \circ$, Thalasseus bergii cristatus (Stephens).

Ponape Id. IV, 26, 1914.

$2 \hat{o}, 1$ ค, $2 \odot$. Sterna albifrons sinensis Gmelin.

To-ko, Formosa. VI, 3, 1917.

Philopterus armatus Johnston \& Harrison.

Johnston \& Harrison, 1912, p. 370, fig. 7, 8, 9 \& 10.

$6 \hat{\delta}, 9$ 우 $6^{\circ}$ were obtained on an Indian curlew, Numenuis arqu ta orientalis Brehm shot in Pref. Kagoshima, Sept. 15, 1918.

My specimens closely agree with Philopterus armatus which was found by Johnston \& Harrison on an Whimbrel, Numenius variegatus from the Kermadecs Id., except the size is much smaller. Measurements of the present specimens are as follows (Numbers in parentheses are those of original description):

\begin{tabular}{l|l|l|l|l|}
\hline & $\begin{array}{c}\hat{\delta} \\
\mathrm{mm}\end{array}$ & $\begin{array}{c}\hat{\delta} \\
\mathrm{mm}\end{array}$ & $\begin{array}{c}\text { + } \\
\mathrm{mm}\end{array}$ & $\begin{array}{c}\text { क } \\
\mathrm{mm}\end{array}$ \\
\hline Length of body & $1.85(1.98)$ & 1.74 & $2.15(2.42)$ & 2.06 \\
Width of body & $0.77(0.91)$ & 0.79 & $0.99(1.05)$ & 0.99 \\
Length of head & $0.58(0.67)$ & 0.57 & $0.66(0.74)$ & 0.66 \\
Width of head & $0.64(0.69)$ & 0.63 & $0.77(0.84)$ & 0.77 \\
Length of prothorax & 0.14 & 0.14 & 0.15 & 0.15 \\
Width of prothorax & 0.30 & 0.30 & 0.36 & 0.36 \\
Length of metathorax & 0.23 & 0.22 & 0.27 & 0.25 \\
Width of metathorax & 0.46 & 0.46 & 0.54 & 0.55 \\
\hline
\end{tabular}

Philopterus shakushigi* n. sp. (Fig. 10).

$1 \circ$ obtained by Dr. N. Kuroda from an Eastern whimbrel, Numenius phaeops variegatus (Scopoli) shot on the River Amur, Corea, May 3, 1917.

This new species is a member of Piaget's shore-bird infesting group Latitemporalis, somewhat resembling to Philopterus fusiformis Denny from Tringa subarquata, but is destinguished from it by smaller size and broader abdomen. It departs from the known forms from Numenius in having the emarginate clypeal front.

Description of the female:-Body small but broad; length $1.40 \mathrm{~mm}$, width $0.68 \mathrm{~mm}$; ground colour of body pale yellowish brown, with brownish markings on head and thorax

\footnotetext{
* "Shakushigi" in Japanese means whimbrel or curlew.
} 
and brownish lateral and yellowish brown transverse bands on abdomen.

Head, length $0.49 \mathrm{~mm}$, width $0.44 \mathrm{~mm}$, conical; uncoloured frontal part of clypeus slightly expanded and emarginate; a hair arising from dorsal surface near anterior angle, projects foreward beyond the margin; behind it a short and a long hairs; two short. marginal hairs, and further two longish hairs in front of trabeculae; trabeculae long, slender, acutely tipped; antennae short, the first segment long, extending beyond antennal sinus, the second longest, the fifth longer than the third or the fourth which is the shortest and about equal length. Temporal angles with three long pustulated hairs and a prickle, and a marginal hair just behind the eye; occipital margin slightly convex in the middle and slightly concave each side of middle; signature long, pale smoky brown, with slightly concave anterior margin, posterior acuminate point darker coloured; suture distinct; dark brown antennal bands, continuing in front of suture, behind it angularly curving; occipital bands distinct, diverging and separated from antennal bands by a broad uncoloured line.

Prothorax, length $0.18 \mathrm{~mm}$, width $0.27 \mathrm{~mm}$, subquadrangular, pale medianlly, with dark lateral bands; posterior angles rounded; posterior margin convex. Metathorax, length $0.20 \mathrm{~mm}$, width $0.39 \mathrm{~mm}$; pentagonal with three pustulated hairs and a prickle in posterior lateral angles; a series of seven pustulated hairs ranged along posterior lateral margins beginning at lateral angles; posterior margin is distinctly angulated on the abdomen; segment mostly pale brownish with a dark lateral blotch in each lateral angle extending indistinctly along latero-anterior borders; legs yellowish with dark brown markings.

Abdomen, length $0.68 \mathrm{~mm}$; width $0.63 \mathrm{~mm}$; broadly ovate, widest at the fourth segment; posterior angles protruding, bearing one to three hairs on segments II-VIII; dorsal surface of abdomen with a transverse series of hairs on the posterior margins of the segments; lateral bands golden brownish which become indistinct on posterior segments and end at seventh segment; transverse band yellowish brown, indistinct, narrower inward, and leaving a broad, whitish median space which becoming narrower on segments V, VI and VII; transverse band of segment VIII forms one continuous blotch covering the whole space between the lateral bands; segment IX entirely brown; the last segment small, uncoloured with emarginations.

\section{Philopterus fusiformis (Denny).}

3ocophorus fusiformis Denny, 1842, p. 82, pl. I, fig. 2; Giebel, 1874, p. 104; Piaget, 1880, p. 86, pl. VI, fig. 7; Kellogg, 1899, p. 58, pl, V; fig. 3.

$1 \hat{s}$ was taken on an Eastern little stint, Calidris ruficollis ruficollis (Pallas) shot in Pref. Nagano. May 21, 1914.

\section{Philopterus auratus (Nitzsch).}

Docophorus auratus Nitzsch, 1818, p. 290; Denny, 1842, p. 78, pl. IV, fig. 5; Giebel, 1874, p. 108, Taf. XI, fig. 2. 6; Piaget, 1880, p. 78, pl. V, fig. 8; Mjöberg, 1910, p. 121.

19,6 collected from an woodcock, Scolopax rusticola rusticola L., killed on the Id. Hachijo of the Seven Ids. of Izu, July, 1922. 
Measurements:

\begin{tabular}{l|c|c|c}
\hline \hline \multicolumn{1}{c|}{} & $\begin{array}{c}\text { q } \\
\mathrm{mm}\end{array}$ & $\begin{array}{c}\text { o } \\
\mathrm{mm}\end{array}$ & $\begin{array}{c}\text { o } \\
\mathrm{mm}\end{array}$ \\
\hline Length of body & 1.87 & 1.80 & 1.47 \\
Width of body & 0.86 & 0.65 & 0.63 \\
Length of head & 0.58 & 0.57 & 0.56 \\
Width of head & 0.68 & 0.54 & 0.50 \\
Length of prothorax & 0.13 & 0.13 & 0.14 \\
Width of prothorax & 0.34 & 0.26 & 0.27 \\
Length of metathorax & 0.37 & 0.30 & 0.23 \\
Width of metathorax & 0.50 & 0.33 & 0.36 \\
\hline
\end{tabular}

The adult female of the present specimens closely correspond to Piaget's description and figure except that the posterior angles of prothorax have one hair and posterior angles of temples have two long hairs, while Piaget's specimen has a prothorax without hair and temples with only one hair, whereas it differs from Nitzsch's and Giebel's auratus in that they have markedly short and broad clypeus and truncate front of clypeus.

Mjöberg has named the Philopterus taken on woodcock as auratus and reports as follows :

"Von einer Scolopax rusticola liegen mir viele Exemplar einer Docophorus-Art vor, die betreffs der Körperform und der Farbe gut mit dieser überinstimmen. Piaget hat unter demselben Namen eine Art abgebildet, doch stimmt die mir vorliegende Art weniger gut damit überein, ist dagegen viel besser mit der Nitzschén übereinstimmend. So bildet $z$. B. Piaget der Clypeus kürzer und mehr parallelseitig ab, auch ist nach ihm Clypeus am Vorderand gerade abgestumpft. Dies ist aber bei der Art Nitzschés nicht der Fall; vielmehr ist clypeus hier nach vorn zugespitzt und am Vorderrande gänzlich bogenförmig gerundet. Die Genitalfiecke sind aber von demselben aussehen."

Among the specimens I obtained immature female differ markedly from the adult female. Immature female have long, narrow clypeus and convex clypeal front, as Nitzsch's and Giebel's descriptions record. At first, I took these two forms to be of distinct species but after examining dètails, despite such conspicuous differences, I came to conclude that these two forms to be in the different stages of the same species.

By the above stated reason, it is possible that three specimens described by Nitzsch, Giebel and Mjöberg, can be the immature stages of auratus.

Philopterus temporalis (Giebel).

Docophorus temporalis Giebel, 1874, p. 102; D. cordiceps, Piaget, 1880, p. 80 \& p. 664, pl. VI, fig. 2, pl. LIV, fig. 7; Kellogg, 1899, p. 5, pl. I, fig. 2.

$2 \hat{\circ}, 2 \odot$ were collected from a lapwing, Vanellus vanellus (L) taken in Pref. Nagano, March 21, 1915.

This specimens agree well in size witin the specimens taken on a Tringa macularia from Panama collected by Kellogg. Measurements of the present specimens are as follows: 


\begin{tabular}{l|c|c}
\hline & $\begin{array}{c}\hat{O} \\
\mathrm{~mm}\end{array}$ & $\begin{array}{c}\hat{\mathrm{m}} \\
\mathrm{mm}\end{array}$ \\
\hline Length of body & 1.62 & 1.60 \\
Width of body & 0.72 & 0.70 \\
Length of head & 0.56 & 0.55 \\
Width of head & 0.61 & 0.60 \\
Length of prothorax & 0.14 & 0.13 \\
Width of prothorax & 0.28 & 0.28 \\
Length of metathorax & 0.19 & 0.20 \\
Width of matathorax & 0.45 & 0.45 \\
\hline
\end{tabular}

Philopterus semivittatus (Giebel).

Docophorus semivittatus Giebel, 1874, p. 102; Piaget, 1880, p. 82, pl. VI, fig. 4; Docophorus semivittatus? Uchida, 1920, p. 636.

Numerous specimens of this species were taken on the following three species of plovers.

1ิ, 6 우 1 . Charadrius dubius curonicus Gmelin.

Pref. Nagano. May 11, 1916.

2॰ Charadrius dubius curonicus Gmelin.

River Baniu, Pref. Kanagawa. June 27, 1917.

2 i Charadrius leschenauitii leschenaultii Lesson.

Pref. Nagano. Oct. 1, 1915.

10 Charadrius alexandrinus dealbatus (Swinhoe).

Suitei-rys, Formosa. Jụne 6, 1917.

This widely distributed Philopterus among Charádrius, closely allied to the preceeding species, but remarkably smaller. As already has been pointed out by Waterston,* this form should be applied to Giebel's Semivittatus.

Measurements of the specimens on hands are as follows:

\begin{tabular}{l|c|c|c}
\hline & $\begin{array}{c}\hat{0} \\
\mathrm{~mm}\end{array}$ & $\begin{array}{c}\text { q } \\
\mathrm{mm}\end{array}$ \\
\hline Length of body & 1.26 & 1.70 & 1.80 \\
Width of body & 0.64 & 0.78 & 0.90 \\
Length of head & 0.43 & 0.54 & 0.53 \\
Width of head & 0.54 & 0.65 & 0.65 \\
Length of prothorax & 0.14 & 0.14 & 0.15 \\
Width of prothorax & 0.25 & 0.28 & 0.28 \\
Length of metathorax & 0.18 & 0.26 & 0.27 \\
Width of metathorax & 0.37 & 0.47 & 0.47 \\
\hline
\end{tabular}

Philopterus fuliginosus (Kellogg).

Docophorus fuliginosus Kellogg, 1896a, p. 80, pl. III, fig. 2

* Waterston, 1914, On some ectoparasites in the South African Museum, Ann. S. A. Mus., vol. X, p. 280. 
17 collected by Dr. N. Kuroda from an Eastern golden plover, Charadrius dominicus fulvus Gmelin, killed at Haneda, Pref. Tokyo, Sept. 25, 1916.

Philopterus validus var orientalis n. var. (Fig. 11).

$11 \hat{\imath}, 2 \%, 3 \odot$ were collected on a streaked shearwater, Puffinus leucomelas (Temmink) taken off the Island Genkai, Pref. Fukuoka, Aug. 3, 1918 and 1 o was obtained from a same host species, shot at Shizuura, Pref. Shizuoka, Aug. 1816, both specimens were collected and presented by Dr. N. Kuroda.

All the present specimens agree well with the type species* from Puffinus gavia but are uniformly much smaller. In this point, my specimens allied to var. minos. Kellogg and Kuwana** on Puffinus subalaris, but differ from it in the shape of head of the female which is much broader than long.

Genitalia of the male somewhat resembles that of the species found on Auks. The basal plate is composed of a pair of slender, curved rods, contracted gradually on the basal portion; each rod of the basal plate furnishing of a long, broad, curved paramera which is straight for the two thirds of its length, thereafter it contract suddenly and end at the sharp point: the endmera, are long, triangular in shape, convex externally and doubly concave internally, with sharp recurved apex. The mesosome nearly fill intraparameral area. The penis is long and straight.

Measurements :

\begin{tabular}{|c|c|c|c|c|c|c|c|}
\hline & $\stackrel{\hat{\delta}}{\mathrm{mm}}$ & $\underset{\mathrm{mm}}{\hat{\mathrm{m}}}$ & $\stackrel{\hat{o}}{\mathrm{~mm}}$ & $\begin{array}{c}\hat{o} \\
\mathrm{~mm}\end{array}$ & $\begin{array}{c}\stackrel{9}{+} \\
\mathrm{mm}\end{array}$ & $\begin{array}{c}\stackrel{+}{\mathrm{mm}} \\
\mathrm{mm}\end{array}$ & $\begin{array}{c}\text { 9 } \\
\mathrm{mm}\end{array}$ \\
\hline Length of body & 1.57 & 1.62 & 1.55 & 1.57 & 1.80 & 1.70 & 1.62 \\
\hline Width of body & 0.78 & 0.77 & 0.77 & 0.68 & 0.92 & 0.87 & 0.80 \\
\hline Length of head & 0.61 & 0.61 & 0.59 & 0.61 & 0.57 & 0.61 & 0.62 \\
\hline Width of head & 0.61 & 0.60 & 0.59 & 0.60 & 0.65 & 0.70 & 0.70 \\
\hline Length of prothorax & 0.18 & 0.18 & 0.17 & 0.17 & 0.19 & 0.18 & 0.17 \\
\hline Width of prothorax & 0.32 & 0.33 & 0.32 & 0.32 & 0.35 & 0.36 & 0.36 \\
\hline Length of metathorax & 0.18 & 0.18 & 0.18 & 0.18 & 0.20 & 0.20 & 0.20 \\
\hline Width of metathorax & 0.42 & 0.43 & 0.42 & 0.41 & 0.47 & 0.48 & 0.47 \\
\hline
\end{tabular}

\section{Philopterus productus (Piaget).}

Docophorus productus Piaget, 1880, p. 87, pl. VI, fig. 8.

2 , 3 ? were oblained on an Indian cattle egrett, Bubulcus ibis coromandus (Boddaert), shot by Mr. Horii in Pref. Kagoshima, Aug. 26, 1917.

\section{Philopterus milvi (Mjöberg).}

Docophorns milvi Mjöberg, 1910, p. 109, Tab. 3, Fig. 1.

$2 \hat{\circ}, 3$ 우 were taken from a black-eared kite, Milvus Migrans lineatus (Gray) shot in.

* Kellogg and Chapmann, New Mallophaga III, 1899, p. 56, pl. V, fig. 2.

** Kellogg and Kuwana, Proc. Wash. Acad. Sci. vol. IV, 1902, p. 461. 
Pref. Nagano and 3$\hat{\mathrm{o}}$ : were obtained on a Formosan black-eared kite, Milvus migrans formosanus Kuroda, shot in Formosa, April 4, 1917.

\section{Philopterus •nisi (Denny).}

Docophorus nisi Dènny, 1841, p. 109, pl. 3, fig. 11; Docophorus gonorhynchus Giebel, 1861, p. 526; Piaget, 1880 , p. 20, pl. I, fig. 3.

The following numerous specimens were collected from four species of birds of prey. $13 \hat{\text { o }, ~} 19$. Butastur indicus (Gmelin)

Toyohi-mura, Pref. Yamagata, Dec. 3, 1923.

$3 \hat{\circ}, 4$ 우 11 . Accipiter virgatus gularis (T. \& S.).

Pref. Nagano, Oct. 21, 1916.

2 ^ิ, 3 ㅇ, 1๑. Pernis apivorus japonicus Kuroda.

Pref. Nagano, Nov. 15, 1917.

\section{Philopterus platyrhynchus (Nitzsch).}

Docophorus platyrhynchus Nitzsch, in Giebel, 1861, p. 525; Piaget, 1880, p. 19, pl. I, fig. 1 a. The following specimens were found on three species of birds of prey.

\section{2 ㅇ, 3 우, 1๑. Buteo buteo burmanicus Hume.}

Pref. Nagano. April 4, 1916.

2 ㅇ Buteo buteo burmanicus Hume.

Pref. Yamagata, Dec. 1923.

3ิ, 2॰. Accipiter gentilis fujiyamae (Swann \& Hartert).

(No history)

2 ๖, 4 ㅇ. 2 ๑ Haematornis cheela perplexus (Swann).

Id. Ishigaki, Loo-choo Ids. Dec. 21, 1923.

\section{Philopterus rostratus (Nitzsch:}

Docophorus rostratus Nitzsch, in Burmeister, 1838, p. 427; Denny, 1842, p. 87, pl. II, fig. 4; Giebel, 1874, p. 76, Tab. X, fig. 4; Piaget, 1880, p. 27, pl. I, fig. 7; Kellogg, 1896, p. 486, pl. LXVI, fig. 7.

$3 \hat{\delta}, 8$ ㅇ, 2 - taken on a feathered-toed scops owl, Otus bakkamoena semitorques T. \& S., shot in Pref. Aomori, May 21, 1923.

\section{Philopterus cursor (Nitzscin).}

Docophorus cursor Nitzsch, in Burmeister, 1838, p. 426; Denny, 1842, p. 101, p. II, fig. 1; Giebel, 1874, p. 75, Tab. XI, fig. 5, 6; Piaget, 1880, p. 24, pl. I, fig. 5.

$3 \hat{\delta}, 4$ 우, 3 ๑. were collected on a short-eard owl, Asio flammeus flammeus (Pontoppidan), shor at Funabashi, Pref. Chiba, Dec. 14, 1923.

Piaget's specimens were taken from the same host species with mine, which show distinctly larger size. The measurements are as follows (those of Parentheses are Piaget's): 


\begin{tabular}{l|l|l|l|l|l|l|}
\hline \hline & $\begin{array}{c}\hat{\delta} \\
\mathrm{mm}\end{array}$ & $\begin{array}{c}\hat{o} \\
\mathrm{~mm}\end{array}$ & $\begin{array}{c}\hat{o} \\
\mathrm{~mm}\end{array}$ & $\begin{array}{c}\text { } \\
\mathrm{mm}\end{array}$ & $\begin{array}{c}\text { f } \\
\mathrm{mm}\end{array}$ & $\begin{array}{c}\text { \% } \\
\mathrm{mm}\end{array}$ \\
\hline Length of body & $1.92(1.7)$ & 1.92 & 1.93 & $2.25(1.9)$ & 2.25 & 2.25 \\
Width of body & $0.81(0.74)$ & 0.83 & 0.82 & $1.00(0.89)$ & 1.00 & 0.97 \\
Length of head & $0.63(0.55)$ & 0.67 & 0.63 & $0.70(0.63)$ & 0.68 & 0.68 \\
Width of head & $0.59(0.53)$ & 0.61 & 0.59 & $0.63(0.59)$ & 0.66 & 0.64 \\
Length of thorax & 0.41 & 0.40 & 0.40 & 0.45 & 0.46 & 0.47 \\
Width of thorax & 0.50 & 0.52 & 0.51 & 0.54 & 0.56 & 0.54 \\
\hline
\end{tabular}

Philopterus cursor var laticephalus n. var.

$8 \hat{o}, 15$ क were collected from a Yamashina's wood-owl, Strix aluco Yamadae Yamashina, shot on the Id. Ishigaki, Loo-choo Ids, Dec. 18, 1923 and $1 \hat{o}, 3 \%$ taken from a Kiushiu ural owl, Strix uralensi; fuscescens T \& S. killed in Pref. Kagoshima, March 10, 1911.

The present specimens are smaller than the preceeding species, taken on short-eared owl, while the present form agrees with the Piaget's type species, in this respect, but it can be readily recognized by the broad, short head, namely, the length of the head is about equal to the width. The New World form, infesting great-horned owl, Bubo virginianus which was collected by Kellogg* has also broad head. The American specimens, however, markedly larger than the present variety. I make a variety, therefore, for them.

The measurements of the present variety are as follows (those in parentheses are Kellogg's):

\begin{tabular}{l|l|l|l|l|l|l|}
\hline & $\begin{array}{c}\hat{\delta} \\
\mathrm{mm}\end{array}$ & $\begin{array}{c}\hat{\delta} \\
\mathrm{mm}\end{array}$ & $\begin{array}{c}\hat{\delta} \\
\mathrm{mm}\end{array}$ & $\begin{array}{c}\text { o } \\
\mathrm{mm}\end{array}$ & $\begin{array}{c}\text { o } \\
\mathrm{mm}\end{array}$ & $\begin{array}{c}\text { \% } \\
\mathrm{mm}\end{array}$ \\
\hline Length of body & $1.72(1.9)$ & 1.75 & 1.75 & $1.95(2.22)$ & 1.92 & 2.05 \\
Width of body & $0.74(0.75)$ & 0.76 & 0.77 & $0.80(0.90)$ & 080 & 0.85 \\
- Length of head & $0.63(0.62)$ & 0.63 & 0.64 & $0.66(0.66)$ & 0.64 & 0.70 \\
Width of head & $0.63(0.62)$ & 0.63 & 0.63 & $0.66(0.66)$ & 0.63 & 0.68 \\
Length of thorax & 0.40 & 0.41 & 0.40 & 0.40 & 0.41 & 0.43 \\
Width of thorax & 0.53 & 0.53 & 0.52 & 0.57 & 0.53 & 0.54 \\
\hline
\end{tabular}

Philopterus superciliosus (Nitzsch).

Docophorus superciliosus Denny, 1842, p. 69, pl. III, fig. 9 ; Giebel, 1874, p. 94, 'Tab. X, fig. 3; Piaget, 1880, p. 39, pl. III, fig. 1.

The following specimens were collected from two species of woodpeckers.

1ิ, 5 우, 1․ Dryobates major hondoensis Kuroda.

Pref. Yamagata. Dec. 31, 1923.

2 ㅅ, 2 ㅇ. $2 \odot$. Dryobates major hondoensis Kuroda.

Pref. Nagano. April 9, 1915.

4 ô, 3우, 3○. Picus awokera awokera Temminck.

* Kellogg: New Mallophaga III, 1896, p.484, pl. LXVI, fig. 1. 
(No history)

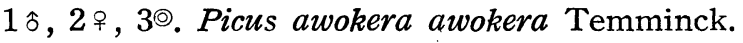

Pref. Yamagata. Jan. 2, 1924.

This well known Philopterus of woodpeckers has been recorded in Europe on Great spotted woodpecker, Dryobates major and on Green woodpecker, Picus viridis. In my collection this species was taken from $D$. major and from Picus awokera (nearest akin of $P$. viridis which is found in Hokkaido), and probably $\mathrm{P}$. viridis in Hokkaido is infested by this parasite:

There is a considerable variation in the individuals of this species as far as the size is concerned. Howerer it seems hardly worth to indicate these varietal differences by name.

Their variation occur on the specimens taken from the same host species and even from the specimens taken from the same individual of hosts.

\section{Philopterus kumagera* n. sp. (Fig. 12).}

1 우 was taken on a great black woodpecker, Dryocopus martius martius (L.), shot at Hachimantai, Pref. Akita, June, 1921.

This new species belongs to Piaget's group Angustifrontes, found on the woodpeckers and presents the characteristic narrow clypeal front, the small trabeculae, but it differs from typical members of angustifrontes in the possession of broad abdomen instead of elongate Nirmoid body.

Description of the male:-Body small, length $1.65 \mathrm{~mm}$, width $0.27 \mathrm{~mm}$; with comparatively large head; ground colour of body pale yellowish brown with narrow dark brown markings on head and thorax and yellowish brown bands on abdomen.

Head, length $0.54 \mathrm{~mm}$, width $0.58 \mathrm{~mm}$; triangular, with somewhat wider frontal apex than in other philopterus of this group; two short hairs in anterior clypeal angles, one at suture, one shorter one between angle and suture, and two rather long hairs in front of trabeculae; the trabeculae are acute and reach to the end of the first segment of antennae; antennae long and slender, with the second segment longest, and the fourth shortest, the basal segment thickend; eyes clear, each with a hair and brown fleck; temporal margin convex, with two long hairs and a prickle; occipital margin slightly convex and bare; Ground colour of head pale yellowish brown with distinct dark brown antennal bands; indistinct pale coloured signature; narrow dark brown marginal band completely encircles. each of the temples; occipital bands indicated, especially at their posterior ends.

Prothorax small, length $0.15 \mathrm{~mm}$, width $0.28 \mathrm{~mm}$; with rounded, rectangular posterior angles and sightly convex posterior margin, with one hair at posterior angles; lateral borders pale, bend inward at posterior angles. Metathorax broad, length $0.22 \mathrm{~mm}$, width $0.50 \mathrm{~mm}$; remarkably produced laterally and posteriorly angulated on abdomen; beginning in lateral angle seven long hairs along each latero-posterior margin, the mesal third of the posterior margin being free from hairs; lateral border pale yellowish brown bend 
inward at posterior angles. Legs pale yellowish with distinct dark brown marginal markings.

Abdomen broadly ovate, length $0.92 \mathrm{~mm}$, width $0.72 \mathrm{~mm}$; widest at the fifth segment; the first segment shortest at side, other segment almost equal in length; posterior angles of segments projecting little or not. at all at sides, bearing a single longish hair in segments III, IV, two hairs in segments V-VII, three hairs in segment VIII; the last segment broadly rounded, bearing several long hairs; dorsal surface of the abdomen with a transverse series of hairs on median portion of the posterior margins of the segments and one row of hairs behind the spirables on the posterior margin, lateral band narrow, translucent pale brown; median transverse band yellowish brown covering whole space between the lateral bands. Genitalia distinct, reaching from the middle of the sixth abdominal segment to the end of the last segment; basal plate weakly chitinized; paramere well chitinized, bend inward at the middle; the endmere slender, with sharp, recurved apex, the penis is long and straight.

\section{Philopterus maruhashi* n. sp. (Fig. 13).}

$1 \hat{\jmath}, 3$ o of this new species, in company with $1 \hat{o}$ of Philopterus subflavescens, were corrected from a Formosan lesser scimitar babler, Pomatorhinus ruficollis musicus Swinhoe, shot at Shinnen-sho, Formosa, May 30, 1917.

This new species allied to Piaget's group Delatatoclypeati or latifrontes in the shape of head, but is different from them by small, narrow abdomen.

Measurements:

\begin{tabular}{l|c|c|c|c}
\hline & $\begin{array}{c}\hat{o} \\
\mathrm{~mm}\end{array}$ & $\begin{array}{c}\uparrow \\
\mathrm{mm}\end{array}$ & $\begin{array}{c}q \\
\mathrm{~mm}\end{array}$ & $\begin{array}{c}q \\
\mathrm{~mm}\end{array}$ \\
\hline Length of body & 1.55 & 1.80 & 1.88 & 1.78 \\
Width of body & 0.55 & 0.57 & 0.61 & 0.65 \\
Length of head & 0.62 & 0.70 & 0.68 & 0.68 \\
Width of head & 0.56 & 0.66 & 0.62 & 0.63 \\
Length of prothorax & 0.20 & 0.22 & 0.22 & 0.21 \\
Width of prothorax & 0.30 & 0.37 & 0.36 & 0.35 \\
Length of metathorax & 0.21 & 0.24 & 0.24 & 0.24 \\
Width of metathorax & 0.47 & 0.54 & 0.55 & 0.55 \\
\hline
\end{tabular}

Description of the male:-Head large in comparison with total size of body, the head larger than one third of the total body length, abdomen small and narrow; ground colour of body pale brownish, with smoky brown markings.

Head latifrontes type of Piaget; clypeal region expanded anterolaterally, with free margin hyaline throughout, front broad with shallow, rounding emargination, and bearing on each lateral angle two long, incurved setae; a long hair on dorsal surface behind setae; a short hair on the margin in front of a distinct suture and two long marginal hairs before the trabeculae; trabeculae long, straight, pointed, coloured with pale brown;

\footnotetext{
* "Maruhashi" in Japanese means scimitar babler.
} 
antennae short, with the second segment longest, the last three segments shorter, subequal; eyes not distinct, with a long hair; temples evenly rounded, narrowly margined with smoky brown, bearing two long hairs and three prickles, occipital margin straight, even slightly concave, noticeable at last medially; signature very broad, cup-shaped, with concave anterior margin, posterior angle long, produced, acuminate; antennal bands reddish brown, interrupted by the distinct clypeal sutures and evalescing with broad distinct widely diverging occipital bands; temporal margins narrowely edged with dark brown.

Prothorax quadrangular, with anterior end deeply projecting beneath the head, posterior margin weakly convex; posterior angles rectangular, bearing a long, pustulated hair; colour pale brownish, with smoky brown lateral bands which expands into triangular blotches in posterior angles. Metathorax pentagonal, with sides convex and strongly diverging; posterior angles bearing four pustulated hairs and a prickle; fourteen or sixteen pustulated hairs on the margin which is acutely angled on the abdomen; lateral margin bordered with smoky brown. Legs long, pale smoky brown, with dark brown markings.

Abdomen small, narrow, elongate ovate; posterior angles of segments I and II broadly projecting under the following segments, posterior angles III to VII slightly projecting, with three to five long hairs, segments I-VII with narrow, elongate, dark brown transverse blotches, blunt apex inwardly, each bearing six to eight pustulated hairs, one near the lateral margin of the blotch, all along the posterior margins of the blotch; transverse blotches of the segment VIII narrow, transversal, nearly continuous; segment IX wholly coloured with dark brown; outer margins of each transverse blotch broadly smoky brown, producing dark lateral bands; posterior margin of the segment IX rounded, bearing a few weak, longish hairs.

Description of the female: Generally similar to the male; body larger than that of the male; ninth segment two lobed, remarkably projecting, with numerous weak hairs.

Philopterus hiyodori* n. sp. (Fig. 14).

2 우 were taken on a Brown-eard bulbul, Ixos amaurotis amaurotis (Temminck), shot on the Niijima Id. of the Seven Ids of Izu, April 20, 1916.

This new species belongs to Piaget's group Dclatatoclypeati infesting the birds of prey, but is characterized by the peculiar shaped abdomen.

Description of the female:-Body, length $2.23 \mathrm{~mm}$, width $1.00 \mathrm{~mm}$; Head large in comparison with the body; abdomen small, oval, widest at the third segment, ground colour of head and thorax yellowish brown, with clear brown or blackish brown markings, colour of abdomen pale reddish brown, with clear brown or reddish brown markings.

Head large, triangular; length $0.81 \mathrm{~mm}$, width $0.78 \mathrm{~mm}$; front of head before the trabeculae elongate and markedly narrowing anteriorly; clypeal region expanded anterolaterally, with free margin hyaline throughout, anterior margin with shallow, rounding emargination, and bearing on each lateral angle two long, incurved setae; a longish hair on dorsal surface behind setae, a short hair on the margin in front of a distinct suture 
and two long marginal hairs before the trabeculae; trabeculae long, straight, pointed, coloured with pale yellowish brown; antennae long, basal segment thickend and as long as the second segment, the third and the fourth shortest, subequal, the fifth, segment slightly longer than the fourth segment; eye very prominent, projecting postero-laterally; temples rounded, parrowly margined with dark brown, bearing long hairs and two or three prickles, also a marginal hair just behind the eye; occipital margin nearly straight, the middle third slightly convex; clypeal signature orange brown, distinct, bottle-shaped, with truncate anterior margin, sides slightly convex, long, posterior acuminate point blackish; a pair of well marked, reddish brown occipital bands continued as antennal bands, running foward to the clypeal sutures, these bands of even width and distinctness throughout their length; even beyond the sutures two small blotches may be looked on as continuation of these bands.

Prothorax short, broad, length $0.21 \mathrm{~mm}$, width $0.45 \mathrm{~mm}$; with sides diverging, posterior angles acute, protruding, bearing a long hair; posterior margin convex; lateral bands distinct, reddish brown and bending in along the posterior margin. "Metathorax short, length $0.27 \mathrm{~mm}$, width $0.60 \mathrm{~mm}$; sides convex, strongly diverging posteriorly, posterior angles obtuse with three long pustulated hairs; posterior margin sinuous, very obtusely angled on abdomen and with eight long pustulated hairs; large transverse, reddish brown lateral blotches separated by a narrow, uncoloured, mesal linear space." Legs concolourous with the body with reddish brown markings.

Abdomen small, length $1.10 \mathrm{~mm}$, width $1.00 \mathrm{~mm}$; ovate broadest at the third segment, posterior margin of the first segment strongly covex, each segment almost equal in length; posterior angles of segments projecting a little laterally, bearing one to three hairs on segments II-VII; dorsal surface of each abdominal segment with ten to twelve long hairs on the posterior margin; segments I-VII with distinct reddish brown, lateral triangular blotch, outer margin of each triangular blotch broadly, clear brown, producing lateral abdominal bands; segment VIII with transverse blotch extending entirely across the segment; segment IX very small, uncoloured, with slight emargination and only a few weak hairs.

Philopterus hibari: n. sp. (Fig. 15).

6 우 3 응 of this new form were collected from a Formosan skylark, Alauda arvensis sala Swinhoè shot in Formosa, June 6, 1917.

A Nirmus-like form, allied to the Angustifrontes group of Piaget, but with broadly truncate clypeal front.

This new species somewhat resmbles Philopterus panamensis Kellogg, but is quite different from it by the shape of head and by smaller size.

Description of the female:-Body, length $1.40 \mathrm{~mm}$, width $0.48 \mathrm{~mm}$; narrow nirmoid; ground colour of head and thorax pale yellowish with distinct, clear brown markings; abdomen whitish with brownish lateral bands.

Head, length $0.44 \mathrm{~mm}$, width $0.30 \mathrm{~mm}$; elongate conical, large in comparison with total

* "Hibari" in Japanese means Skylark. 
size of body, that part of the head in front of the mandibles specially long; uncoloured front of clypeus expanded anteriorly, fiatly rounded with convex anterior margin; a short marginal hair at the base of uncoloured clypeal front, a hair on the margin in front of the suture, and two marginal hairs before the trabeculae; a short dorsal hair at each side of the base of uncoloured clypeal front, another long hair on dorsal surface behind it; trabeculae large, pointed, uncoloured; antennae medium, with the segments first and second subequal, the fifth segment shorter and segments third and fourth equal and shortest; eyes prominent, bearing a long hairs; temporal margin fiatly convex, with two long hairs and a prickle; occipital margin slightly concave; ground colour of head pale yellowish brown, with narrow, clear brown antennal bands; pale, indistinct signature and narrow, clear brown temporal margins fading out posteriorly, occipital bands indicated especially at their posterior ends.

Prothorax, length $0.11 \mathrm{~mm}$, width, $0.20 \mathrm{~mm}$; posterior angles almost rectangular with one hair, posterior margin slightly convex; ground colour pale yellowish with clear brown lateral border extending inward along the posterior margin. Metathorax, length $0.18 \mathrm{~mm}$, width $0.35 \mathrm{~mm}$; sharply angulated on abdomen, posterior angles with two long and a short hairs and each lateral posterior side bearing three long pustulated hairs; lateral borders broadly clear brown; legs paler, than body with yellowish brown marginal markings.

Abdomen, length $0.77 \mathrm{~mm}$, width $0.48 \mathrm{~mm}$; elongate elliptical; with lateral margins of segments nearly equal and more or less convex and the posterior angles bearing one or two hairs in segments II-VIII; six or eight weak, long hairs on dorsal surface of segments in transverse series; ground colour whitish with distinct clear brown, narrow latetal bands, and indistinct, yellowish transverse band; segment. IX small, uncoloured, deeply emarginate, with a minute hair on each posterior margin.

Philopterus suzume* n. sp. (Fig. 16).

$2 \hat{\circ}, 2 \circ, 2^{\circ}$ were collected from a Japanese tree sparrow, Passer montanus saturatus Stegneger shot in Pref. Nagano, Feb. 23, 1917 and 2 우 in company with Philopterus subflavescens, were collected on a Japanese meadow bunting; Emberiza cioides ciopsis Bonaparte shot in the same locality. Feb. 22, 1917.

This new species belongs to Piaget's group Angustoclypeati infesting starlings and mynas and characterized by smaller size and broad semicircular abdomen of the male.

\begin{tabular}{|c|c|c|c|c|c|c|}
\hline & \multicolumn{4}{|c|}{ on Passer montanus } & \multicolumn{2}{|c|}{ on Emberiza cioides } \\
\hline & $\stackrel{\hat{o}}{\mathrm{~mm}}$ & $\stackrel{\hat{\delta}}{\mathrm{mm}}$ & $\begin{array}{c}\stackrel{9}{7} \\
\mathrm{~mm}\end{array}$ & $\stackrel{\circ}{\mathrm{P}}$ & $\stackrel{q}{\mathrm{~m}}$ & $\begin{array}{c}\stackrel{+}{7} \\
\mathrm{~mm}\end{array}$ \\
\hline Length of body & 1.35 & 1.10 & 1.42 & 1.31 & 1.38 & 1.35 \\
\hline Width of body & 0.52 & 0.52 & 0.62 & 0.62 & 0.59 & 0.59 \\
\hline Length of head & 0.38 & 0.38 & 0.44 & 0.43 & 0.44 & 0.44 \\
\hline Width of head & $0 . \dot{39}$ & 0.38 & 0.44 & 0.44 & 0.44 & 0.43 \\
\hline Length of thorax & 0.21 & 0.20 & 0.28 & 0.28 & 0.27 & 0.27 \\
\hline Width of thorax & 0.30 & 0.30 & 0.38 & 0.38 & 0.37 & 0.36 \\
\hline
\end{tabular}

* "Suzume" in Japanese means Tree sparrow. 
Description of the male: body small, head triangular, abdomen short, broad; ground , colour of body pale yellowish brown, with yellowish brown and clear brown markings.

Head triangular, forehead tapering, front of clypeus narrow and concave, with two short hairs in the anterior angles, one longish hair between clypeal suture and trabeculae, a hair and a prickle in front of trabeculae; trabeculae long, acute, reaching the middle of the second segment of antennae; antennae long, the second segment longest, the first segment thickend, shorter than the second, the fifth longer than the third or the fourth segment, which is shortest and both are about equal; eyes clear, prominent, with a long hair and a prickle; temples rounded, bearing a long hair and three prickles; clypeal signature pale, indistinct; suture distinct antennal bands, ocular blotch and anterior portion of temporal borders clear brown; occipital band yellowish brown, strongly diverging anteriorly and bend inward to the ocular blotch and coalescing with the base of the antennal bands; occipital margin sinuous, bearing a prickle on each side.

Prothorax short, sides slightly diverging posteriorly, posterior angles rectangular, with a long pustulated hair; posterior margin evenly convex; lateral bands distinct, clear brown. Metathorax short, broad; sides strongly diverging lateral angles obtusely rounding with a short spine; posterior margin very flatly convex on abdomen, with an angular indication at middle; nine pustulated hairs on each side of the posterior margin; lateral border ill defined, with reddish brown transversal lateral blotch extending from each side. Legs concolourous with the body.

Abdomen broad, nearly circular, broadest at the fourth segment, lateral margins of segments nearly equal and more or less convex, the posterior angles bearing two to three hairs in segment III-VIII; segments I-VII with narrow; elongate, dark brown transverse blotches, blunt apex inwardly; dorsal surface of each abdominal segment with a row of long hair, on the posterior margins; transverse blotches of the segment VIII narrow, transversal, continuous; segment IX large, uncoloured, rounded, bearing a few longish hairs; outer margins of each transverse blotch broadly clear brown, producing dark lateral bands.

Description of the female: body larger than that of the male; abdomen longer and elliptical; transverse blotches of the I, II and VIII abdominal segments continuous, IX segment small, emarginate.

\section{Philopterus sturni affinis (Piaget).}

Docophorus leontodon var affinis Piaget, 1880, p. 67, pl. V, fig. 3; Uchida, 1920, p. 637. $5 \hat{\delta}, 7$ ㅇ were colected on three specimens of Formosan crested-myna, Aethiopsar cristatella formosana Hartert taken at Reiko. (June 13), at Nanpeisho (June 4), and at Chosu (June 7) in 1917.

\section{Philopterus sturni var acutifrons n. var.}

1 ㅇ of this new form was taken on a Amami brown-eared bulbul, Ixos amaurotis ogawae (Hartert), collected on the Id. Amami-oshima, March 22, 1919. 
While this specimen closely resembles Philopterus sturni Schrank, it can be scarecely called that and has accordingly been given varietal rank.

This variety is distinguished from the type species by the larger but comparatively narrower head, (length $0.53 \mathrm{~mm}$, width $0.48 \mathrm{~mm}$ ) by the narrower and deeply emarginated clypeal front and by absence of hairs on the posterior angles of the prothorax.

Philopterus mukudori* n. sp. (Fig. 17).

$2 \hat{\text { o }}$ were taken on a gray starling, Spodiopsar cineracea (Temminck), shot at Funabashi, Pref. Chiba, Dec. 14, 1925.

Measurements :

\begin{tabular}{l|c|c}
\hline & $\begin{array}{c}\hat{\delta} \\
\mathrm{mm}\end{array}$ & $\begin{array}{c}\hat{\delta} \\
\mathrm{mm}\end{array}$ \\
\hline Length of body & 1.83 & (abdomen broken) \\
Width of body & 0.80 & 0.63 \\
Length of head & 0.65 & 0.62 \\
Width of head & 0.62 & 0.18 \\
Length of prothorax & 0.18 & 0.34 \\
Width of prothorax & 0.36 & 0.22 \\
Length of metathorax & 0.24 & 0.53 \\
Width of metathorax & 0.53 & \\
\hline
\end{tabular}

Description of the male:-Head comparatively large; ground colour of body pale yellowish brown, with very distinct reddish brown markings on head, thorax and abdomen, transverse band of abdominal segments dark brown, covering whole space between the lateral bands.

Head comparatively large, conical, sides of the forehead slightly concave, rapidly approaching each other anteriorly; front truncate or feebly concave, lateral angles obtusely rounded, two rather long, stiff hairs on dorsal surface in rounded anterior angle and extending foreward beyond the margin of the head, a short hair on the margin in front of a distinct suture, before and behind suture, each a long hair on dorsal surface, projecting beyond the margin, two rather long hairs before the trabeculae; trabeculae large pointed, reaching nearly to the end of the fifth segment of the antennae, well coloured with pale yellowish brown; antennae long, with the second segment longest, segments third and fifth equal and the fourth segment slightly shorter than the third; eyes small but prominent, bearing a long hair and a fleck; temples broadly rounded with two long hair and two prickles; signature yellowish brown, very distinct with truncate anterior margin, sides covex, long, posterior acuminate point coloured; antennal bands distinct, reddish brown, interrupted by the suture, .darker and widening at base; occipital bands distinct reddish brown, diverging and with anterior extremities reaching the darker, curving end of the antennal bands; occipital margin weakely sinuous; *the middle third slightly convex.

\footnotetext{
* "Mukudori" in Japanese means starlings.
} 
Prothorax short, quadrangular, with sides diverging, posterior angles acute, bearing a hair and a prickle; posterior margin fiatly convex; lateral bands distinct, reddish brown extending in along the posterior margin. Metathorax short, broad, sides strongly diverging posteriorly, lateral angle rounded, bearing two long pustulated hairs, one short hair and a prickle; posterior margin obtusely angled on abdomen and with ten or twelve pustulated hairs along posterior margin; lateral bands distinct, reddish brown, segment pale in middle. Legs short with bright brownish, marginal markings.

Abdomen broadly. elliptical; widest at the fourth segment; posterior angles protruding, bearing one to three hairs on segments II-VII, eighth segment very short; ninth segment broadly rounded, with a few hairs; lateral bands distinct, reddish brown; transverse bands broad, pale brownish, entirely across all segment; a single transverse series of weak, pustulated hairs along the posterior margin of each segment; distinct, uncoloured stigmatic spots.

\section{LIST OF REFERENCES}

In this bibliography are enumerated only those papers which are referred to in the text. Publications marked with *were not accessible to the writer.

1) Burmeister, H.: 1838, Handbuch der Entomologie Bd. II, pp. 41-138.

2) Clay, Theresia: 1935, Two new genera of Mallophaga (Proc. Zool. Soc. London, pp. 615-618, 4 figs.).

3) Cummings, B. F.: 1916, Studies on the Anoplura and Mallophaga, pt. II. (Proc. Zool. Soc. London, pp. 643-693, figs. 1-36).

4) *Degeer, C.: 1752-1778, Mémoires pour servir a l'histoire des Insectes, 7 vols.

5) Denny, H.: 1842. Monographia Anoplurolum Britanicae.

6) Defour, L.: 1835. Description et iconographie de trois espèces du genre Philopterus, parasites de l'Albatros. (Ann. Soc. Ent. de France, Tome IV, pp. 669-680, pl. XXI.).

7) Eichler, W.: 1940a, Notulae Mallophagologicae I. (Zool. Anzeiger, 129 (516) pp. 158-162).

8) Eichler, W.: 1940b, Notulae Mallophagologicae IV. (Zool. Anzeiger, 130 (516) pp. 97-103).

9) Ewing, H. E.: 1926, Some recent generic derivatives of the Mallophagan genus Philopterus Nitzsch (Proc. Ent. Soc. Wash. Vol. 28, pp. 145-150).

10) Ewing, H. E.: 1929, A manual of external parasites.

11) Fabricius, J. C.: 1775, Systema Entomologicae pp. 804-810.

12) *Geoffroy, Et. L.: 1762, Histoire abrégée des Insects qui se trouvent aux environs de Paris, 2 vols. Paris.

13) Giebel, C. G.: 1866, Die im Zoologischen Museum der Univ. Halle aufgestelten Epizoen nobst Beobachtungen über dieselben. (Zeitsch. f. d. ges. Natur. Bd. XXVIII, pp. 353-397).

14) Giebel, C. G.: 1867, Description of Lipeurus ferox (Zeit. f. d. ges. Nat. XXIX, p. 195).

15) Giebel, C. G.: 1874, Jnsecta Epizoa, Die auf Saügetiere und Vögeln schmarotzenden Insekten, nach Chr. L. Nitzsch Nachschlaus.

16) Giglioli, H.: 1864, On some parasitical insects from China. (Quart. Journ. Micr. Sci. Iv. pp. 18-26).

17) ${ }^{*}$ Grube, A. E.: 1843 , Parasiten (Niddendorf, Reise in die ausersten Norden u. Osten Siberiens, pp. 409-503).

18) *Gurlt, E. F.: 1843, Über die auf Haussä̈getieren und auf Hausvögeln Schmarotzerinsekten. (Magaz. f. d. ges. Tierheilk., Bd. IX).

19) Harrison, L.: 1915, Mallophaga from Apteryx and their significance; with a note on the genus Rallicola. (Parasitology, vol. VIII, pp. 88-100).

20) Harrison, L.: 1916, The genera and species of Mallophaga, (Parasitology, vol. IX, 1-156).

21) Johnston, T. H. and Harrison, L.: 1911, Notes on some Mallophagan generic names (Proc. Linn. Soc. N., S. Wales, vol. XXVI, pp. 321-328).

22) Johnston, T. H. and Harrison, L.: 1912, On a collection of Mallophaga from the Kermadecs. 
(Trans. N. Zeal. Inst. vol. XLIV, pp. 364-373).

23) Kellogg, V. L.: 1896a, New Mallophaga I. (Proc. Cal. Acad. Sci., Ser. 2, vol. VI, pp. 31-168, pl. II-XV).

24) Kellogg, V. L.: 1896b, New Mallophaga II. (Proc. Cal. Acad. Sci., Ser. 2, vol. VI, pp. 451-548, pl. LX-LXXIII).

25) Kellogg, V. L.: 1899, New Mallophaga III. (Occasional papers of the Cal. Acad. Sci., vol. VI, pp. 1-224, pl. I-XVII).

26) Kellogg, V. L.: 1910, Mallophaga, Gen. Insect. fasc. 66. Kellogg, V. L.: 1914, Mallophaga from birds of the S. Atlantic (Sci. Bul. Mus. Brooklin Inst. Arts \& Sci. vol. 2, pp. 80-88, pl. XVI).

27) Kellogg \& Chapman: 1902, Mallophaga from birds of the Pacific coast of N. America. (J. N. Y. E. Soc. vol. 10, pp. 20-28, pl. III).

28) Kellogg \& Kuwana, S. I.: 1902, Mallophaga from Alaskan birds. (Proc. Wast. Acad. Sci., vol. IV, pp. 457-499, pl. XXVIII-XXXI).

29) Kellogg \& Paine, J. H.: 1911, Anoplura and Mallophaga from African hosts. (Bull. of Entomol. Research vol. II, pp. 145-152, pl. IV and V).

30) Kellogg \& Mann, W. M.: 1912, A third collection of Mallophaga from Alaskan birds. (Ent. News, XXIII, pp. 12-17, fig. 1 \& 2).

81) Linnaeus, C.: 1758, Systema naturae, 10th, Edition.

32) *Lyonet, P.: 1832, Recherches sur l'anatomie et les metamorphoses de defferentes espećes d'insectes. Posthumous woak, edited by De Haan.

33) Mjöberg, E.: 1910, Studien über Mallophagen und Anopluren. (Arkiv för Zoologi, Bd. VI, pp. 1-296, pl. I-V).

34) Neumann, L. G.: 1906, Notes sur les Mallophages-I. (Bull. Soc. Zool. France, XX, p. 54-60).

35) Neumann, L. G.: 1913, Notes sur les Mallophages-III. (Arch. Parasit., thme XV, pp. 608-634).

36) *Nitzsch, C. L.: 1818, Die Familien und Gattungen der Tierinsekten. (Germar's Magazin d. Entom. III).

37) *Nitzsch, C. L.: 1866, Die Feterling sing-Schrei-Klettel und Taubenvogel. (Zeit. f.. d. ges Nat. XXVIII, 115-122).

38) *Piaget, E.: 1878, Akidoproctus n. g. (Tijdschr. v: Ent. XXI, p. 178).

39) Piaget, E.: 1880, Les Pediculines.

40) Piaget, E.: 1885, Les Pediculines, Suppl.

41) *Rudow, F.: 1870, Beobachtungen über die Lebensweise und den Bau der Mallophagen. (Zeitschr. f. d. ges. Nat. Bd. XXXV).

42) Schrank, F.: 1776, Beiträge zur Naturgeschichte.

43) Scopoli, J. A.: 1763, Entomologica carniolica.

44) Taschenberg, O.: 1882, Die Mallophagen mit besonderer Berücksichtung der von Dr. Meyer gesammelten Arten.

45) Thompson, G. B.: 1935a, Preliminary descriptions of three new genera of Mallophaga. (Ann. Mag. Nat. Hist. XV, pp. 148-151).

46) Thompson, G. B.: 1935b, Notes on Mallophaga-III. (Ann. Mag. Nat. Hist. XVI, pp, 214-217).

47) Thompson, G. B.: 1935c, A new genus of Mallophaga allied to Pseudonirmus Mj. together with note on the genus Naubates Bd. (Ann. Mag. Nat. Hist. Ser. 10, XVI, pp. 485-488).

48) Thompson, G. B.: 1936, Three new genera of Mallophaga (Ann. Mag. Nat. Hist. vól. XVIII, pp. 40-43).

49) Uchida, S.: 1916, Bird-infesting Mallophaga of Japan. II. (Annot. Zool. Japon. IX, pp. 81-88).

50) Uchida, S.: 1917a, Mallophaga from birds of Formosa. (Journ. Coll. Agr., Imp. Univ. Tokyo, III, pp. 171-188, pl. X).

51) Uchida, S.: 1917b, Bird-infesting Mallophaga-III. (Annot. Zool. Japon., IX, pp. 201-215).

52) Uchida, S.: 1918, Mallophaga from birds of the Ponape I. and Palau Is. (Ann. Zool. Japon., IX, pp. $481-493$ ).

53) Uchida, S.: 1920, On the second collection of Mallophaga from Formosan birds. (Annot. Zool. Japon. IX, pp. 635-652).

54) Waterston, J.: 1914a, On some ectoparasites in the S. African Museum, Cape Town. (Ann. S. Afr. Mus. X, pp. 271-321).

55) Waterston, J.: 1914b, An account of the Bird-lice of the genus Docophorus found on British Auks (Proc. Roy. Phys. Soc. Edinb. XIX, pp. 149-158).

56) Waterston, J.: 1915, An account of the Bird-lice of the genus Docophorus found on British Auks. pt. II. (Proc. Roy. Soc. Edinb., XIX, pp. 171-176). 

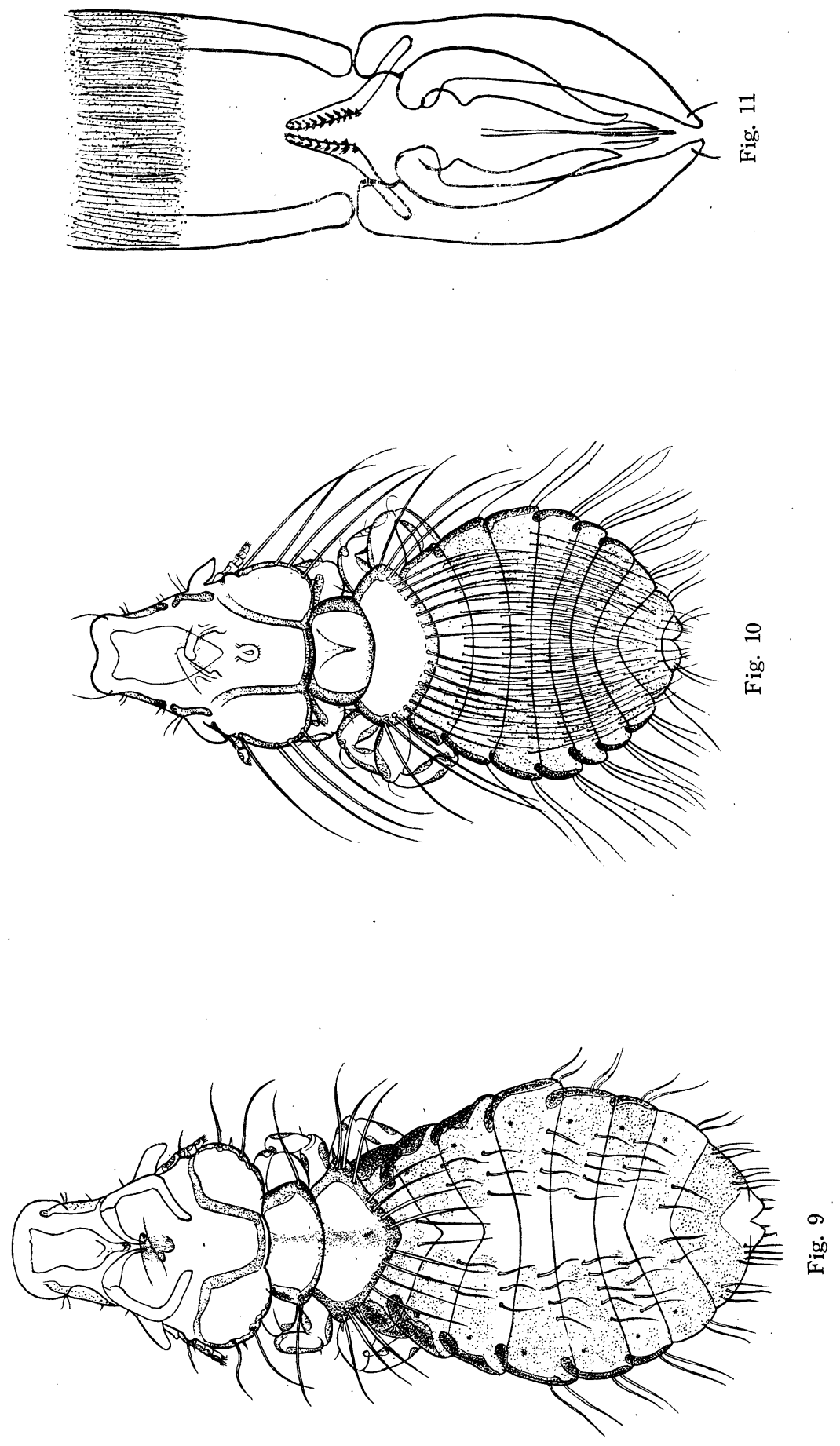

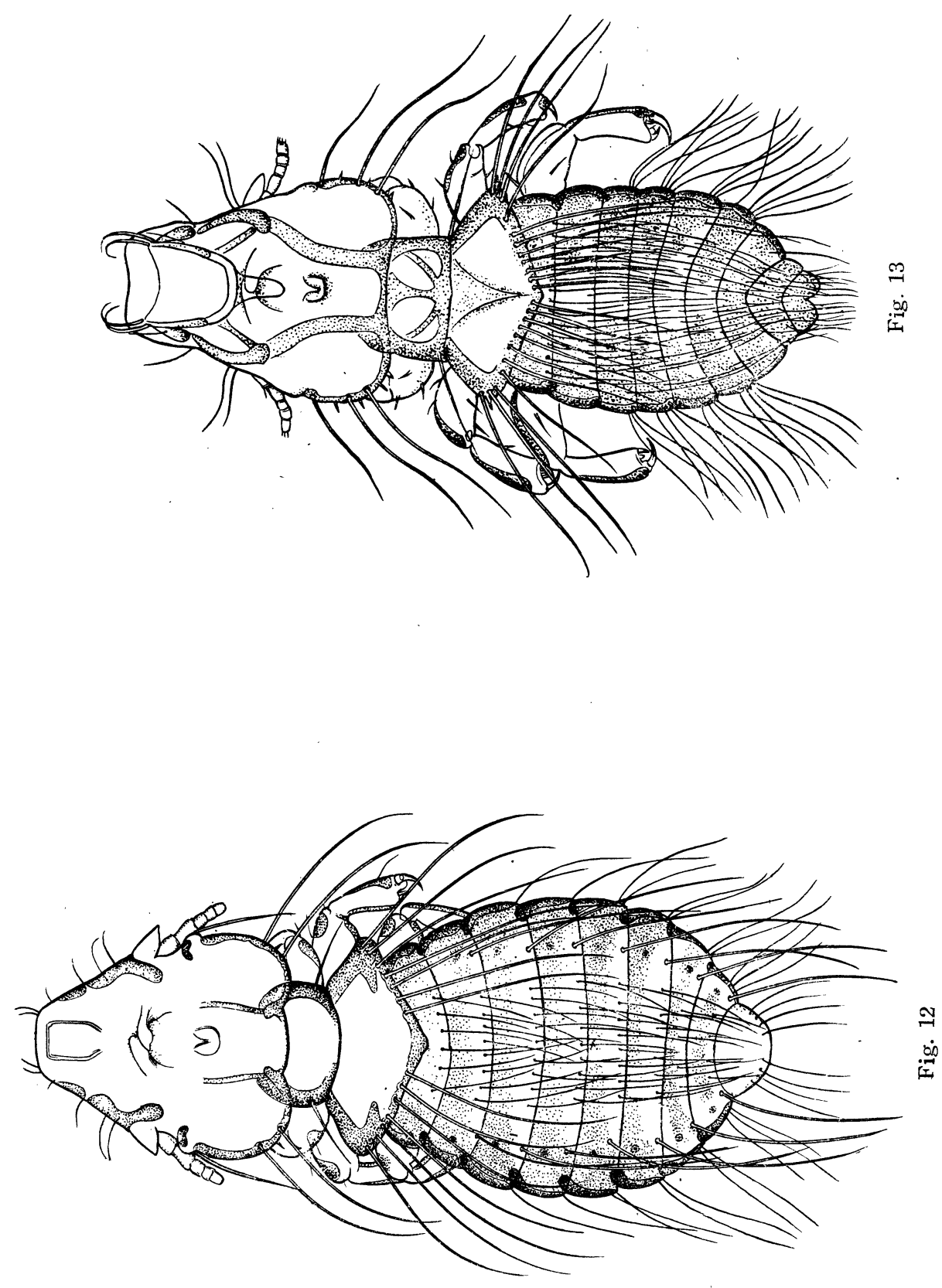

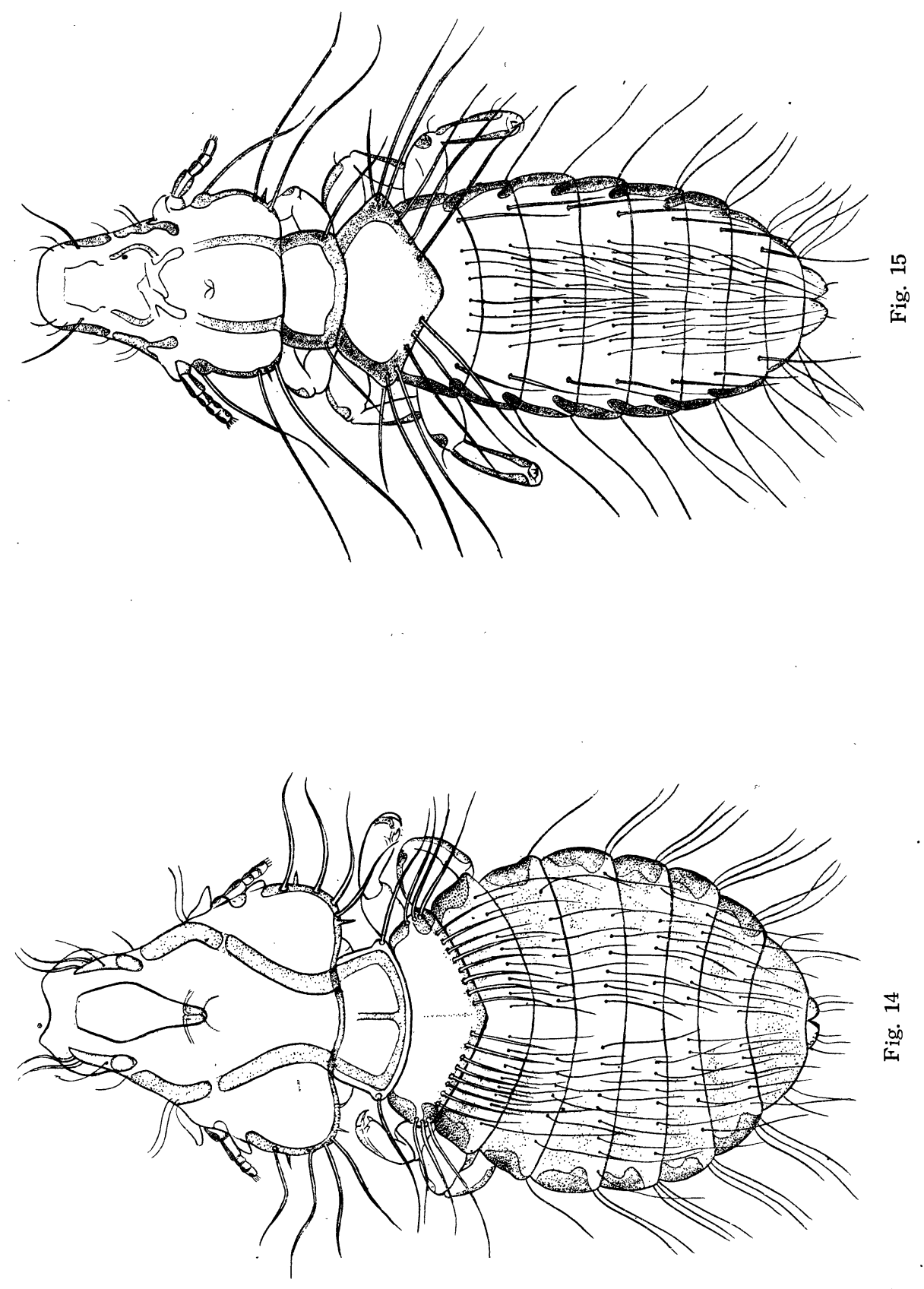

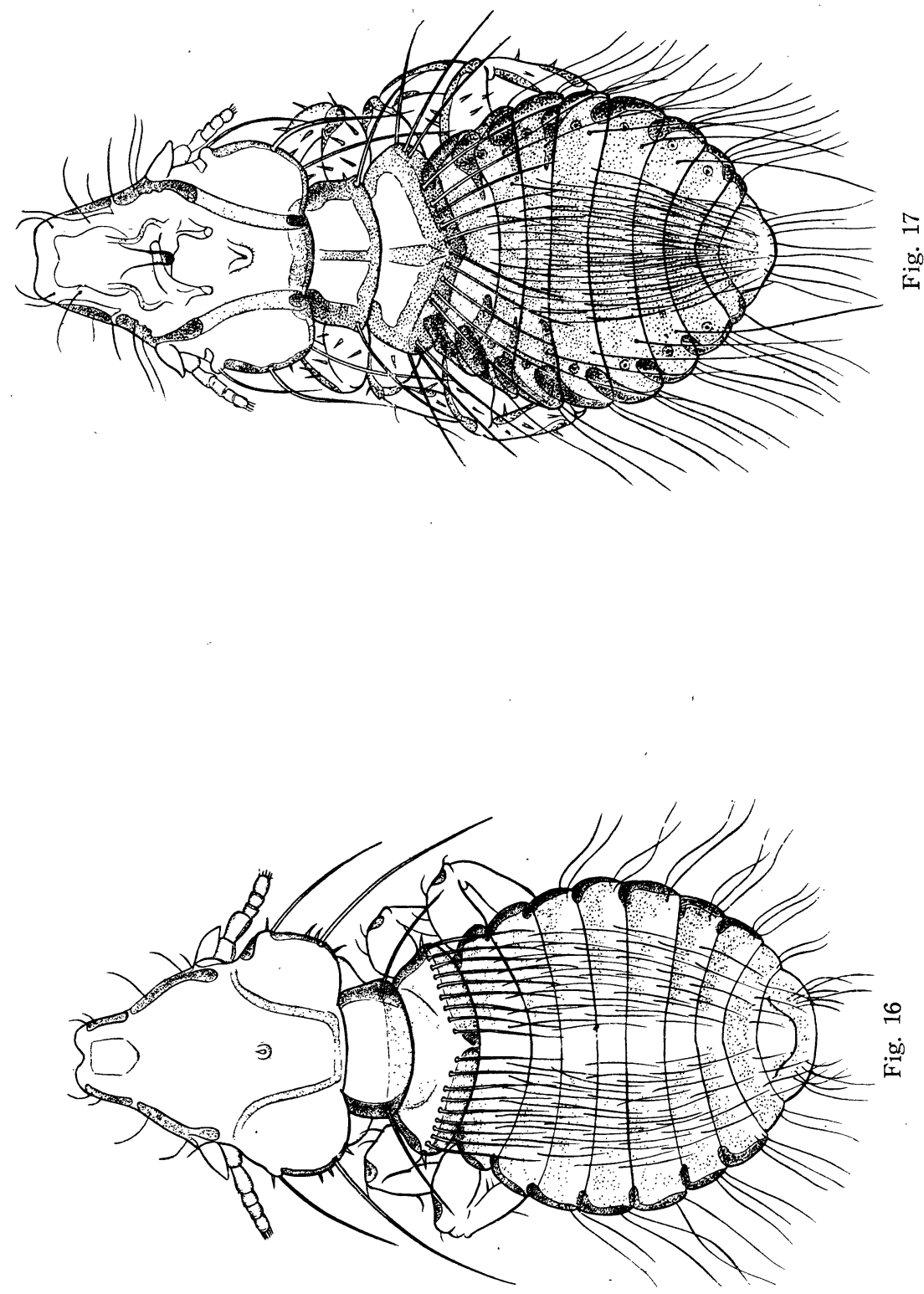